\title{
15
}

\section{Ireland: A Shift Towards Religious Equality 2 in Schools

\section{Introduction}

The purpose of this chapter is to provide an overview of the three main 6 research traditions that have emerged in Ireland over the past four decades: 7 cultural and religious diversity in policy documents and research reports; rac- 8 ism and education; and the development of newer and more critical research 9 agendas. Increasing migration-related diversity can be seen as a challenge for 10 schools, especially in newly immigrant-receiving countries such as Ireland. 11 Previously largely homogenous in cultural terms, teachers and school princi- 12 pals in Ireland are increasingly faced with the challenge of addressing the 13 needs of all students and not favouring one group over another while acknowl- 14 edging that schools should strive to create an environment where all children 15 feel valued and views and learning of all students is supported. This chapter 16 begins with an overview of the Irish educational system, and moves on to 17 outline the main immigration phases and patterns including levels of diver- 18 sity. It then discusses each of the three main research traditions we have iden- 19 tified in turn through a synthesis and analysis of the main literature available. 20

D. Faas $(\bowtie)$

Trinity College Dublin, Dublin, Ireland

e-mail: daniel.faas@tcd.ie

R. Fionda

University College Dublin, Dublin, Ireland

e-mail: rachael.fionda@ucd.ie 
In the final section, building on the identified main research traditions, we offer possibilities for researchers to engage in new directions of migration and educational research in Ireland, for instance around policy versus practice in schools.

\section{The Irish Educational System}

Schooling in Ireland is compulsory from the age of six until 16. Most primary schools are privately owned but state-funded and provide education for children from the ages of four to 11 or 12 years. Around $96 \%$ of primary schools are denominational in their intake and management, with $90 \%$ of all primary schools under Catholic patronage (McGarry 2017). Alternative option to parents is provided by the new multidenominational Community National (CN) and Educate Together (ET) schools. CN schools were set up in response to parental demand in areas with considerable numbers of immigrants, and where children were not able to secure places in local schools. Since 2008, 12 such schools have been established, providing an additional option for parents, and are designed to meet the demand for a different approach in providing religious and moral education (see cns.ie, Faas et al. forthcoming). These schools provide faith formation for different religious groups during the school, distinctly different from the approach adopted by the currently 90 ET schools (81 primary plus 9 secondary schools, see educatetogether.ie/schools) that teach children about different world religions with an optional faith formation component after school, organized by the parents. There has been a growing demand for alternative schools, as the proportion of the population who do not belong to the Catholic faith has increased. During the past three years, ET schools have increased by over $50 \%$. There are also two state-funded Islamic primary schools in Ireland, both in Dublin, and one Jewish school. All state schools follow a centralized curriculum. Pupils are not generally permitted to repeat a school year (see Department of Education 2003). A revised primary school curriculum was launched in 1999 and outlines six areas: language; mathematics; social, environmental and scientific education (history, geography and science); arts education (music and drama); physical education; and social, personal and health education. Curriculum and assessment are centralized on a national basis, by the National Council for Curriculum and Assessment (see ncca.ie).

In the Republic of Ireland young people enter lower secondary education at 12 or 13 years of age. Participation in full-time education is compulsory until the age of 16 , or three years of lower secondary education, whichever is 
later. There are 723 secondary schools in Ireland, of which 376 are 58 denominational voluntary secondary, 254 vocational and 93 community/ 59 comprehensive schools. Voluntary secondary schools, traditionally more aca- 60 demic in focus, are privately owned and controlled, mainly by religious orders. The vast majority of voluntary secondary schools are Catholic, with a small number of minority faith schools. Vocational schools are publicly owned and are administered by education and training boards (ETBs) and have greater practical orientation. There is also a small number (about $8 \%$ ) of private feepaying schools. Community and comprehensive schools were established in an attempt to bridge the gap between the previously-mentioned two school types, by providing a broad curriculum catering for pupils of different backgrounds and ability levels. The types of school not only differ in their student composition, with a greater concentration of working-class and lower ability students in vocational schools (Hannan et al. 1996), they are often also more accessible to migrant students (see Table 15.1).

The second-level curriculum is divided into two cycles: a three-year junior cycle (generally catering for students $12-15$ years of age) and a two-year senior cycle (generally catering for students 16-18 years of age). At both junior and senior level students can be 'streamed' according to ability; those considered to have higher academic potential study for and take exams at 'Higher Level' and those of average ability study at 'Ordinary Level' (Maths, English, and Irish can also be studies at 'Foundation Level'; see www.curriculumonline.ie for more details). Students can self-select which levels they take, in consultation with their subject teachers. There are significant implications; Higher Level exam results are worth double in the points system required for university entry (see www.cao.ie). Between the junior and senior cycles students may

Table 15.1 Overview of the Irish education system

\begin{tabular}{|c|c|c|c|}
\hline $\begin{array}{l}\text { Primary } \\
\text { education }\end{array}$ & $\begin{array}{l}\text { Secondary education: } \\
\text { junior cycle }\end{array}$ & $\begin{array}{l}\text { Secondary education: } \\
\text { senior cycle }\end{array}$ & $\begin{array}{l}\text { University } \\
\text { education }\end{array}$ \\
\hline $\begin{array}{l}\text { Pre-primary } \\
\text { schooling } \\
\text { (age 3/4) } \\
\text { Senior and } \\
\text { junior infants } \\
\text { (age 4-6) }\end{array}$ & $\begin{array}{l}3 \text { years (age } 12 / 13 \text { to } \\
15 / 16) \\
\text { Voluntary, } \\
\text { vocational, } \\
\text { community and } \\
\text { comprehensive } \\
\text { schools }\end{array}$ & $\begin{array}{l}2 \text { years (age } 15 / 16 \text { to } \\
17 / 18 \text { ) } \\
\text { Voluntary, vocational, } \\
\text { community and } \\
\text { comprehensive schools }\end{array}$ & $\begin{array}{l}\text { Generally } 3 \\
\text { years, in some } \\
\text { universities } 4 \\
\text { years until BA } \\
\text { degree }\end{array}$ \\
\hline $\begin{array}{l}\text { Primary } \\
\text { schooling } 6 \\
\text { years (age } 6 \\
\text { to } 12 \text { ) }\end{array}$ & & $\begin{array}{l}\text { Further education: } \\
\text { post-leaving certificate } \\
1 \text { year or apprenticeship } \\
\text { training }\end{array}$ & \\
\hline
\end{tabular}


complete the Transition Year Programme. This is an option for students in some schools while it is compulsory in others. This programme is not examinable and is characterized by curricular flexibility, cross-curricular initiatives, and school-community linkages. Senior-cycle education underwent significant change during the 1990s and is currently the subject of review by the National Council for Curriculum and Assessment (NCCA), including the introduction of a new subject 'Politics and Society'. Although The Irish Times newspaper publishes an annual league table of post-primary schools, the 'accountability movement' is having less of an influence on the Irish educational system compared to countries like the UK (Stevens 2007). Nonetheless, parental choice is emphasised leading to a rather heterogeneous school landscape particularly at primary level. Another difference to the UK is that many schools are not state-run, but instead managed by the (Catholic) church or private bodies who have considerable control over the school ethos and curriculum. Schools in socio-economically deprived areas, so-called DEIS schools, can apply for extra support (i.e. free meals and additional support teachers).

Training for teachers is offered by specialist colleges for primary-level teachers, while second-level teachers complete an undergraduate degree and then a one-year postgraduate course in education at an Irish university. As of September 2014 the traditional Higher Diploma in Education (a postgraduate specialisation course) was replaced by the Professional Master of Education (Teaching Council 2013), or students can take one of five concurrent undergraduate level Bachelor of Science, often with each of the universities specialising in a specific subject (Teaching Council 2013). The postgraduate level course is a two year, full-time course (the Higher Diploma in Education was one year full-time) and incorporated a wider curriculum. Previously to this, courses differed from university to university, and this system had been criticized as providing inadequate preparation for post-primary school teachers (Eurydice 2009). Whether the updated postgraduate education course provides prospective teachers with any grounding in educating the diverse classroom and migrant students is yet to be seen, though diversity and inclusion are highlighted in some course outcomes. Diversity in education was either not covered, or was covered in a deficient manner, and any improvement to this stance has not yet been proven:

The narrow vision of 'Irishness' which was promoted continues to permeate both the education system and society, as evidenced by the continued dominance of the Catholic Church in areas such as school ownership and teacher training, and the persistently ethnocentric curriculum. (Nowlan 2008, p. 255) 
Since the year 2000 the Department of Education and Skills (DES) has restructured itself and assigned certain responsibilities to external agencies such as the State Examinations Commission (Devine 2005; Smyth et al. 2007), the intention of this move being to allow the DES to concentrate on policy issues and allow schools' management to direct the implementation of individual policy, establish their own ethos and organize the delivery of each student's education.

Catholic schools continue to dominate the educational landscape in Ireland and the relative lack of alternatives for minority faith and non-faith groups has resulted in a situation whereby many children attend schools which do not reflect their own beliefs and, in fact, have a strong emphasis on socialisation into the majority faith. At the same time, the intake of migrant children from schools outside Ireland is continuing, albeit at a slower pace than during the economic boom. Each year, during the past decade, a minimum of 3,000 new entrants from outside Ireland to mainstream primary schools have been recorded, with a peak of 8000 per annum around the time of the start of the recession in 2008 (DES statistics). In March 2011, a Forum on Patronage and Pluralism in the Primary Sector was established. The Minister appointed an Advisory Group which recommended the introduction of a common curriculum, Education about Religions and Beliefs (ERB) and Ethics for all primary school children. Recent media debates centre on inclusion at enrolment policy level and parental choice in opting out of the religious ethos and education of a school (Kitching 2013). It is expected that the new School Admissions Bill (2016) will make the enrolment process more equitable. A growing number of multi-denominational schools does not require acceptance of a particular religious philosophy as part of the admissions process, and instead emphasise community factors such as the 'sibling rule' or residence in the local area (Faas et al. forthcoming).

Much literature claims that the disempowerment faced by many students is a reflection of the habitus of the individual educators (Nowlan 2008; Fionda 2011; Darmody et al. 2012), of institution-wide and national policy (Lentin and McVeigh 2006; Kuhling and Heohane 2007; Faas et al. 2015) and of the society in which the educational institution is set. DES recognizes the role disadvantage plays in preventing groups of students from accessing mainstream education: '[educational disadvantage prevents] students from deriving appropriate benefit from education in schools' (DES 1998).

At present, the DES distributes 'circulars' to communicate to schools updates in policy, new policy initiatives, and general business. It is up to the individual school to decide on the best way to implement the policies as set 
out by the DES; the School Inspectorate examines whether the implementation meets the original demands of DES policy via a series of evaluations, either whole school or for each subject department. Little is known about effectiveness and best practices of implementing DES 'circulars' and other DES policies and initiatives (such as the NCCA Intercultural Guidelines 2006, for example). Anecdotal evidence suggests such documents are not routinely used by teachers in practice (Fionda 2011).

\section{Immigration to Ireland}

Although Ireland has always been a destination of in-migration including Celts, Normans, and British, it was the economic boom during the 1990s which brought unprecedented levels of prosperity and helped transform the country into one of net immigration by 1996 (Ruhs 2005). For the first time in its history, Ireland experienced a significant inflow of migrants - both workers and asylum seekers - from outside the European Union (EU). Between 2001 and 2004, Ireland reached new peaks in non-EU immigration flows before a shift occurred toward intra-European mobility from East to West following eastern enlargement of the EU. Ireland, together with Sweden and the UK, allowed migrants from the new member states access to the labour market resulting in considerable inflows of Polish (63,276 in 2006) and Lithuanians (24,268 in 2006). At the beginning of the economic downturn in Ireland, in 2008, there was a general expectation that most migrants would return to their countries of origin. Instead, the number of non-Irish nationals increased by 124,624 or $30 \%$ (CSO 2012, p. 33) between Census 2006 and Census 2011. The increase was particularly marked among Eastern European nationals.

Ireland became a net emigration country between 2008 and 2015, in the wake of the economic recession where unemployment peaked at a rate of over $15 \%$. In 2016, for the first time since 2009, Ireland returned to a net inward migration country. The Central Statistics Office noted that between April 2015 and April 2016, the number of immigrants has increased by almost $15 \%$ from 69,300 to 79,300 while the number of emigrants declined over the same period from 80,900 to 76,200 . Irish nationals continue to experience net outward migration albeit at a much lower level than in previous years falling from 23,200 to 10,700 while net inward migration among non-Irish nationals has grown for the past four years. The latest Census data, collected in April 2016, show particularly large increases among Romanians, Brazilians and Spanish (CSO 2017). 
As reflected in the Census results, there has been a significant growth in the diversity of the population in Ireland. Over the years the non-Catholic population has increased, due to growing numbers of people with 'no religion' (138,264 in 2002 compared with 269,111 in 2011) accompanied by an increase in the number of migrants with different belief systems (up from 89,223 in 2002 to 216,401 in 2011). The number of Catholics reached the lowest point in $2011(3,861,335)$, representing $84 \%$ of the population. A number of primary school-aged children $(14,769$ or $3 \%)$ were recorded as belonging to 'no religion, atheists or agnostics' categories with $6 \%$ belonging to a minority faith background (Faas et al. 2016).

Children of immigrants and non-nationals account for $10 \%$ of the primary school level population (between four and 12 years of age) and $8 \%$ of the post-primary school level population (between 12 and 18 years of age). There is however a difference in the distribution of these students across schools at primary and post-primary levels. At post-primary level the vast majority of schools (90\%) have so-called newcomer students, but many of them have a rather small proportion of between $2 \%$ and $9 \%$. At primary level, over $40 \%$ of schools have no newcomers at all, but those that do, tend to have a greater proportion of newcomer students (ESRI 2009; Byrne et al. 2010).

There are many studies which identify racist attitudes in Irish society in general, as well as in the education system (see for instance Lentin and McVeigh 2006; Keogh and Whyte 2003; Devine 2005; Nowlan 2008). Traditionally 'Ireland lies far behind other European countries in addressing racism in terms of anti-racist legislation' (Tannam et al. 1998, p. 11), though recent equality legislation may point to a shift towards more policies which bring Ireland in line with its European counterparts (Employment Equality Acts (EEA) 1998-2004 and the Equal Status Acts (ESA) 2000-2004). Theories of racism highlight a tendency to give with one hand while taking away with the other; this contradiction is discussed in Lentin and McVeigh (2006). Other studies claim there to be a comparatively sympathetic attitude towards migrants (Turner 2010; such studies may be out of date considering recent economic decline.

\section{Education and Social Policy}

While many European states have adopted a number of different official poli233 cies to deal with migration-related diversity such as assimilation, integration, 234 interculturalism, or multiculturalism (Gray 2006; Mac Éinrí 2007), the 235 debate about cultural diversity, including what the appropriate educational 
response should be, is still very much in its infancy in Ireland (Devine 2011a). Thus immigration has posed a number of challenges for Irish schools, which have had little prior experience of dealing with diversity. These developments in Ireland reflect wider debates about the impact of increased ethnic, cultural, and linguistic diversity on traditional conceptions of citizenship and national identity, and how educational policies and curricula should respond to these challenges (O'Connor and Faas 2012; Faas and Ross 2012).

Despite some progress in providing targeted support for migrant children in Irish schools in the form of additional English-language provision, the recent economic downturn has resulted in significant cuts in the education sector that have also reduced initiatives supporting linguistic and sociocultural inclusion of migrant students. These cuts led to the discontinuation of Integrate Ireland Language and Training, which was established to meet the language and training needs of children from diverse cultural and educational backgrounds, particularly in secondary schools. Over the years, a considerable body of research has built up on school inclusiveness in Ireland (Bryan 2010; Smyth 1999). However, few studies have specifically focused on school-based support mechanisms available for migrants (see Faas et al. 2015). At government level, in 2016, an Education (Admissions to School) Bill was published to ensure all schools have inclusive admissions policy. The legislation targets what the Department of Education and Skills calls soft barriers to admission by forcing schools to publish entrance policies, and make it illegal to turn down a student on grounds of race, religion or disability.

Analysis of recent, context-specific literature uncovers criticism of the way official DES policy for migrants in the school system is constructed and disseminated, and of the non-uniform way in which many schools and teachers implement the policy (Devine 2005; Nowlan 2008; Ó Riagáin 2013), while other studies propose solutions and recommendations (Little 2008; Lyons and Little 2009; Little and Lazenby-Simpson 2009; Fionda 2011). DES response to the changing levels of diversity in society, and therefore in the student population, began in 1999 by making funding available for English language support (Nowlan 2008). Circular 0053/2007 (DES 2007) is entitled 'Meeting the needs of pupils for whom English is a second language' and this three-page document was issued by DES in 2007 to address a situation which had necessitated intervention since the arrival of Ireland's new migrants at least a decade or two earlier. Earlier documents (see DES 2003) set out availability of funding available to support migrants in the school system. Funding centers around offering language support to migrant students, which is meant to support and open access to students' mainstream learning. 
Circular 0053/2007 detailed the first guidelines for official educational provision for migrant students. According to the circular, its purpose is 'to 277 assist schools in providing an inclusive school environment to meet the needs of pupils for whom English is a second language and outline the resources that are available to assist schools in this task' (DES 2007, p. 1). It goes on to provide limited guidelines on the subject of creating an inclusive school environment. The circular offers a brief description of the role of a language support teacher. Many such teachers describe a situation of confusion, isolation, and often blurred boundaries between a school's language support program and its special needs department (Nowlan 2008, p. 261). Many mainstream teachers appear not to inform themselves about matters related to migrant students (Fionda 2011), even though the circulars clearly state that mainstream teachers are responsible for migrant students in their mainstream lessons (DES 2007, 2009).

Circular 0015/2009, intended to replace the previous one, came in response to the recession and subsequent budget cuts across many spheres of Irish life. A review of Circular 0015/2009 indicates that ESL support was reduced to two teachers per school, except for those schools where over 90 students require ESL support. Prior to 2009, a third ESL post required just 42 students. ESL funding was cut to 100 million from 137 million. A further circular (DES 2012) states that language support is effectively discontinued, instead it will be officially merged with learning support, and that teaching allocation will be halved.

A 2011 DES funded and issued report was critical of the practice of both Circulars above, stating that the 2007 Circular 'did not lead to uniform good practice because it was in many ways a move made in isolation, preceding the availability of adequate CPD, assessment instruments and teaching materials, particularly in the post-primary sector' (DES 2011, p. 116). The same report also noted that the 2009 Circular was often regarded by schools only in terms of the allocation received rather than its stated educational aims. Furthermore, the report makes recommendations which support international best practice as set out in the literature though as yet no follow-up Circular has been issued which deals with the recommendations specific only to English language support. Anecdotally, teachers talk of reforms in the ways English language support was allocated in 2012 though there is no written documentation to support this. Typically, since the 2009 Circular, English as an Additional Language (EAL) has been referred to under learning support.

Furthermore, the role of religious bodies as administrators in the education system has led to concern (the vast majority of Irish schools, particularly at primary level, are Catholic, Darmody et al. 2012), particularly 'the exemption 
that denominational schools currently enjoy from equality legislation, allowing them to discriminate in terms of student admissions and teacher appointments in order to protect their ethos' (Nowlan 2008, p. 256), which means that a school can exclude a student from a migrant background on the grounds of their religious background - a practice which has received heavy criticism. Devine (1999) draws our attention to the long history of domination by the church in the education system. The moralization of the young, through religious instruction, continued to be perceived to be 'a fundamental part of the school course' and in line with the overall principles of the curriculum, was to be implemented in an integrated and child-centred manner (Devine 1999, p. 21).

Literature in the field has identified gaps in provision for migrant students in the Irish post-primary system and contributes to emerging literature which addresses educational policies for Ireland's migrant students and practice in schools (Devine 2005; IILT 2007; Little 2008; Lyons and Little 2009; Ó'Riagáin 2013, Faas et al. 2015; Faas et al. forthcoming). Nonetheless, Irish schools perform reasonably well according to international evaluation studies such as the Programme for International Student Assessment (PISA). PISA 2009 showed that Irish-born (native) students and non-Irish-born migrants who speak English at home had significantly higher mean reading scores than migrant students who spoke other languages at home. Unlike in most other European countries, there is no statistically significant performance gap between (first-generation) migrant students and their native peers in Ireland (OECD 2010), though at this early stage, post the significant wave of immigration, it is imprudent to compare to countries with a longer history of immigration. Ireland is also characterized as an inclusive system in terms of the even distribution of migrant students across schools compared to other OECD countries (OECD 2009), despite there being no enforcement of school choice for migrants.

\section{Methodology}

Several factors make the Irish context unique: (a) a shorter history of students from immigrant backgrounds within the education system, (b) a largely denominational education system despite increasing religious diversity and secularisation, (c) relatively heterogeneous distribution of languages within schools, and (d) fewer context-specific studies - research is still emerging but very much in its infancy. The economic downturn appeared to be reversing the trend of funding; interest and research into the area, however, remain. 
Many studies into the Irish educational and migration context necessarily draw upon a wide range of international studies, because Irish-specific research is still emergent and limited. This is due to several interconnected causes; first and foremost that Ireland is traditionally a country of net emigration, and only during its economic boom (the so-called 'Celtic Tiger') from the mid1990s until the crash of 2008 was immigration widespread.

Although, for the factors listed above, it was therefore difficult to source exclusively Irish-context literature it was decided that including only such literature was necessary to maintain the focus on the unique attributes of the Irish perspective. In presenting only studies that focused on Ireland, more effective comparisons may be made with other chapters of this book. Furthermore, and in line with Stevens (2007) and Stevens et al. (2011), and a necessary limitation given the range of Irish literature which exclusively explores the nature of educational inequality and migration, our chapter is restricted to studies conducted between 1980 and 2016. Also in line with the methodologies cited above is the decision to restrict analysis to only secondary education (referred to as second-level education in Ireland), though further rationale behind the decision is particular to the Irish context: the holistic nature of first-level education means that much practical progress has been made regarding provision for migrant students (see Little and LazenbySimpson 2004). However, studies into second-level education are approached from a somewhat distinct perspective, partly due to the divided curriculum (into subject areas) and further divisions for the junior, senior and Transition Year cycles, exam type, and so forth.

In addition, the majority of the sources reviewed were peer-reviewed articles and edited books; however, this guideline was not adhered to as strictly because of the emergent nature of studies relating education and migration in Ireland much of the research carried out has not yet been published officially. Three distinct research approaches emerge from the Irish context: (1) cultural diversity in policy documents and research reports, (2) racism and education, and (3) developing newer and more critical research agendas.

\section{Research Traditions}

In this section, we focus on the specific research questions, methods, results, 386 and related debates characteristic of each of the above-named research tradi387 tions. Emphasis is placed on the Irish-specific developments in terms of social and educational policy and intellectual thought explaining each of the three 388 identified research traditions: charting ethnic inequalities and policy issues; 
racism and education; and developing newer and more critical research agendas.

\section{Cultural Diversity in Policy Documents and Research Reports}

During the aftermath of initial waves of immigration, so from the mid-1990s, the Irish research agenda set out to describe the changes in society, analyze the relationship between the influx of large numbers of people from varying ethnic backgrounds and its resulting effects across political, social, and educational spheres as well as in the labour market, and to shape policy decisions. Such studies focus on pre-existing diversity and discrimination issues at national policy level and paved the way for researchers to address more domain-specific, empirical studies on racism and education (see next research tradition). Aligned with a post-structuralist perspective, the methodologies are descriptive and analytical, identifying trends over time by reviewing policy and literature.

Lentin and McVeigh (2006) provide a key reference study which identifies how inequality in Ireland is addressed via research and policy agendas, but only within an antecedent framework of discrimination, which results in a disparity between policy and practice (a trend which is picked up again in the following research traditions). According to them, racism in Irish society reflected as institutional racism in schools is revealed by, on the one hand, a tendency to 'provide for' minorities (Lentin and McVeigh 2006, pp. 5-6), observe the current wave of 'intercultural' and 'anti-racist' education initiatives (NCCA 2006), and on the other hand reluctance to fully implement educational programs which enable migrants to learn. There is evidence to suggest that debate in Irish society tends therefore to reinforce the unequal distribution of power (Guerin 2002), and attitudes in the media are visibly racist (McVeigh 2002). Policy reflects the white, Catholic hegemony in its viewpoint that racism is 'caused by the 'strangeness' of incoming immigrant groups [rather than by the 'host' society]' (Lentin 2002, p. 229).

There are a profusion of large-scale guidelines and policy documents also embedded in this research tradition; some studies cross over in their purpose between providing exploratory research and suggesting policy implications. The NCCA (2006) and Irish National Teachers' Organisation (INTO) (2005) Intercultural Education Guidelines fall under this category. The more recent Intercultural Education Strategy was launched with the twofold aims of ensuring that 
all students experience an education that 'respects the diversity of values, beliefs, languages and traditions in Irish society and is conducted in a spirit of partnership' ... [and] all education providers are assisted with ensuring that inclusion and integration within an intercultural learning environment become the norm.

The strategy documents a macro-study of the context (demographic details, national legislation, and research overview) as well as setting out components of the strategy and how to implement it. It was launched by the DES in midSeptember 2010 and so if it is to come into practical relevance, the start of the 2011/12 academic year will be the most logical starting point for schools. Anecdotal explorations show the document to be widely ignored in practice.

In 2010, the Economic and Social Research Institute (ESRI) was commissioned by the Integration Centre of Ireland, a migrant NGO which ceased to exist in 2014, to develop an integration monitor to measure the integration of immigrants in Ireland, and publish an annual monitoring report on integration. The reports consist of an overview of the main trends in migration and chapters covering integration policy and national indicators in the domains of employment, education, social inclusion and active citizenship. These indicators will allow for assessment of economic, political and social equality of immigrants in Ireland. The annual reports also identify data gaps in each integration domain, and reflect on the implications of the findings for integration policy. Four such reports were published in total between 2010 and 2014 (McGinnity et al. 2011, 2012, 2013, 2014). In 2016, the Department of Justice began funding the ESRI to continue with this series and an integration report covering 2016 was released in Spring 2017.

Early studies, and follow-up research of policy and guideline documents, argue that opening the doors to its schools but failing to provide the support necessary to access the curriculum is representative of Ireland's migration policy: a policy characterized by legislation which is intended to control rather than liberate those people who are the subjects of Irish racism' (Lentin and McVeigh 2006, p. 2). The issue of race is 'problematized' and 'common sense' legislation (see Gramsci 1971, p. 322, for discussion of 'common sense' notions) seeks to manage 'the problem of racial and ethnic difference' (Lentin and McVeigh 2006, p. 2). There are a wealth of findings from the later research traditions which relate their agenda to the preceding context; namely the identification of structures which pre-date the large-scale increase of immigration and concluding that as such, recent discrimination is indicative of already present problems. Diversity in the Irish population is not new. 'Minority ethnic groups, including the indigenous Traveller community, as well as relatively small immigrant Jewish, Italian and Chinese communities, for example, have

432 433 434 435 436 437 438 439 440 441 442 443 444 445 446 447 448 449 450 451 452 453 454 455 456 457 458 459 460 461 462 463 464 465 466 
been part of Irish society for a long time' (Nowlan 2008, p. 255). So, the influx of immigrants does not initiate or uncover a new problem, it reveals existing problems in the education system.

Parker-Jenkins and Masterson (2013) address education policy via a medium-scale study of 12 post-primary schools which focussed on cultural diversity and how policy translates into practice across areas such as school uniform and the curriculum (hidden or otherwise). The study concludes in identifying the significant challenges in place when moving from a 'Catholic, White and Gaelic' ethos to policies and practices which are inclusive and acknowledge cultural diversity (ibid., p. 489).

Studies from this research tradition set the tone that discrimination in schools reflects inequalities within the broader society. This largely descriptive and analytical research is limited to reviews of existing studies and policy documents. In drawing together existing research on education, legislation overviews, and large-scale demographic reports, the research highlights structures which present obstacles to migrants. The findings also uncover constructs which historically discriminate against other minority groups before the widespread immigration, such as social, cultural and religious barriers, as well as linguistic ones.

\section{Racism and Education}

In Ireland this research agenda, which developed to describe and analyze racism in education in specific response to large numbers of migrants in the school system and affect policy (in theory), emerged from the later 1990s on and has been noticeably responsive over time to the unstable dynamics of the Irish economic circumstances. Many studies draw focus on qualitative and quantitative strategies (which paved the way for triangulation, integrating elements of qualitative approaches in the final research tradition, see next section). For example, a key study in this tradition represents the emerging interest in migration, ethnic minority, and education; Keogh and Whyte (2003), in their study on the experiences and aspirations of immigrant students in second-level schools, draw attention to the fact that within their sample schools, no Traveller students were participating in the senior cycle (Keogh and Whyte 2003).

Studies from the wider European context also contribute to this tradition. According to such research, ESL students do not fare well; students who speak a language other than English at home still face a gap in achievement: 
The immigrant students in Ireland are a heterogeneous group. There is a gap in 503 achievement between those students who speak English at home and those who 504 do not. Ireland aims to provide inclusive, high quality education for all students'. (OECD 2009, p. 9)

This tradition is characterized by a Bourdieuian analysis set in a framework which links academic potential to dominant cultural ideology. In schools, where the culture of the dominant group is promoted, educational differences and failure are often misrecognized as resulting from a lack of academic talent, when in reality they stem from class differences or cultural diversity (Bourdieu and Passeron 1977, 1979). And so, while success at school is celebrated by the dominant social groups as based on merit, Bourdieuian theory questions the idea of a meritocracy and instead suggests a concern that schools merely reproduce dominant ideology by simply refusing to recognize that the established order is problematic (Bourdieu 1993; Mills and Gale 2007). Wacquant (1998) elaborates the theory of cultural capital thus, 'rather than education acting as an equalizer in a prejudiced society with all participants afforded equal opportunity, success in education is based on the cultural experiences, social ties and economic resources that each student has access to' (ibid., p. 216; Mills and Gale 2007, p. 433). Irish studies initiated debate in the research which observed how migrants were subjected to 'quick fix' approaches which devalued their own 'cultural capital.' Keogh and Whyte (2003, p. 8) refer to European and human rights philosophies in their observations that provision for migrant students means not simply asking the students themselves to 'fit in', but rather a long-term and sustained effort on the part of policy-makers and schools to include and value a diverse student population:

A key theme explored in this research tradition further explores the idea of the 532 'gap' in wider inequality and the role of schools in either mitigating or reproducing such social disadvantage (Darmody et al. 2012). Darmody et al. (2012) are among the first to employ a larger scale study which addresses such issues in situ and concludes that cumulative disadvantage is reproduced from the start of a migrant student's educational career; from the point of enrolment, higher than average admittance to designated disadvantaged schools (DEIS) schools, and throughout streaming. 
Further large-scale studies highlight key features of school environments which promote higher levels of (migrant) student success (Fionda 2013; Faas et al. 2015). Strong school leadership, student-centred practices, parental involvement and linguistic support are some of the attributes uncovered by the studies. Such results indicate measures schools can take to mitigate issues of racism in education.

This research tradition draws on a theoretical framework derived from Bourdieu and Gramsci, and relies upon studies from similar contexts (specifically migrant education in the UK and Canada, because these predominantly English-speaking systems have well-developed literature compared to the emerging Irish context). A significant conclusion is that practice in place for many ESL students maintains the privileges and power of dominant cultural ideology, at the cost of provision of equal chances for Ireland's new migrant students. This practice is not overtly enforced but, as Gramscian hegemony illustrates (Gramsci 1971; Cummins 2000; Ferguson 2006) quietly negotiated via procedures where educational structures exclude groups who fall outside the dominant culture, by promoting an assumption where biculturalism and bilingualism are viewed as deficits (Ward 2006), and via a state of confusion which leads to a tolerance and perpetuation of 'worst' practice. In sum, this tradition sets its research in a Bourdieuian framework and focuses on describing a rapidly emerging and new 'status quo' in relation to race and education. It seeks to illustrate, drawing on qualitative and quantitative methods, the challenges faced by education systems and students alike, and concludes that educational parity is not offered in favour of maintaining existing power structures. It is only tentative in any attempt to approach policy propositions, which leads us to the next tradition.

\section{Developing Newer and More Critical Research Agendas}

Key studies in this tradition set out to address what the ideal definition of 'language support' should be in Ireland and what provision for migrant students meets the specific needs of the Irish context. Researchers in this tradition suggest the disparity between policy and practice is an obstructive factor in achieving parity of educational access. This tradition continues to set its agenda within a Bourdieuian framework, and again draws on qualitative strategies.

A key study in this area is the Lyons and Little (2009) research report which widely criticizes both provision and practice. Other studies in this tradition come to similar conclusions: discrimination in schools reflects inequalities 
within the broader society. 'School practices are understood to be influenced by their location within the broader social and policy contexts, as well as by 577 the individual actors in schools - students, teachers and parents' (Nowlan 2008, p. 254; Faas 2010), and much recent research in the field of diversity in Irish schools has concentrated on such issues (Devine 2005). Nowlan (2008) and Devine $(2005,2011 \mathrm{~b})$ are also key contributors to this tradition.

Lyons and Little (2009), Nowlan (2008) and Devine (2005) conclude that Ireland's migrant students face significant obstacles in accessing education: social, cultural and religious barriers, as well as linguistic ones. Research into these issues benefits not only migrant students but also ethnic English and Irish students who, while having been born in Ireland to Irish parents, may face similar obstacles due to their social and/or economic disadvantage, and lay the foundation to prepare all students for participation in an increasingly diverse society. Devine (2011b), in a key study, concurs with Lyons and Little (2009), that as well as drawing migrant children into the curriculum via their English language, schools have to value the cultural and personal backgrounds of the students.

Crozier et al. (2010, p. 209) identified the societal changes which have initiated research trends:

Irish society shifted from being one characterised by intensive periods of emigration, to one of intense immigration. This 'unexpected immigration' during a period of rapid economic development has given rise to renewed challenges related to definitions of national identity and citizenship. Coinciding with changes in the education system arising from processes of modernisation and intense educational reform, old certainties are replaced by insecurities and challenges as to how best to work with increasing ethnic diversity in classrooms and schools.

Crozier et al. (2010) are critical of Ireland's approaches to policy develop604 ment, and Kitching (2010) identifies the dangers in Ireland's apparent reluctance to learn from the mistakes of countries such as the UK in avoiding tension between migrants and local communities.

Nowlan's (2008, p. 253) findings confirm the challenges faced by a system so unprepared for the dramatic change in its student population: 
While diversity has always existed in Irish schools (on socio-economic background and gender grounds, for example), recent immigration has uncovered insufficient provision for a diverse student body within the education system. 'Second language learners, who were seen as the 'barium meal in the X-ray' showing up deficiencies in the schooling system that affected the progress of many other students' (Bourne 2003, p. 26). Critical pedagogy is concerned with the potential role of education as a true preparation for future citizens. 'The social and political dimensions of schooling, the need to understand and transform schools and society, and the key role that educators in these processes play are core themes shared by many critical educators' (Fischman and McLaren 2005, p. 426).

Practice which may be a result of the 'exclusive' origin of Ireland's postprimary schools, when schools were open to only a small number of wealthy families (Hyland 1999, p. 33), is evident in Irish schools. The tendency to stream students in some schools is a legacy of this and Nowlan (2008) points out that many migrant students are placed disproportionately in lower stream groups.

Biggart et al. (2013) addresses issues faced by migrant students who live outside of the urban areas traditionally included in research studies in this area. The study indicates that students in these areas experience low levels of belonging (in particular among Irish Travellers which reinforces the findings across many studies in this chapter which shows how recent inward migration has uncovered pre-existing inequality in policy and practice).

Like many of the context-specific research into inequality, Nowlan's (2008) research identified with Bourdieuian traditions (see preceding research tradition also). Nowlan draws on Bourdieu's ideas of cultural capital, arguing that 'society was stratified according to the possession of cultural as well as economic capital' (Nowlan 2008, p. 254). Nowlan develops this point, reflecting that 'minority language students in particular, may be discriminated against within the education system since they lack the means to acquire the particular cultural capital which is necessary in order to do well at school' and also therefore to participate equally in society after school. According to Bourdieu, migrant students do possess rich cultural capital, that of their varied linguistic abilities and cultural experiences which are distinct from the often (more) homogeneous linguistic and cultural experiences of students born in Ireland (not ignoring the differences in social background of these students). Research shows that 'bilingual students' linguistic abilities are not valued as cultural capital... there is a danger that stereotypes will emerge and become selfperpetuating, resulting in lower expectations on the part of both students and teachers' (Nowlan 2008, p. 262). This contrasts, for instance, with the UK 
where Reay et al. (2011) found that the 'socially inclusive middle-class' student and family actively embraces diversity and is open to difference, seeing themselves further enriched through the consumption of ethno-cultural though not necessarily social - diversity.

Later empirical studies in this area adopt the perspective of institutional intervention programmes and students views of ethnic minority students; Tormey and Gleeson (2012) reported a large scale attitudinal study of second level students which captured early indications of low-levels of social distance with respect to African and Eastern European students. The highest levels of social distance were reported towards Muslim students and Irish Travellers (ibid., p. 165-167). Studies such as this pose to make recommendations and more critical research and policy.

In brief, the tradition addresses and is characterised by a strong focus on qualitative and 'chalk-face' research. Again, set within a Bourdieuian framework, this tradition is more progressive in its forthright approaches towards policy and ideal practice recommendations. It links small-scale case-studies, interviews, and other qualitative methods to broader theories which define some existing practices as inappropriate and puts forward model frameworks upon which to base policy. It builds on agendas set within the Bourdieuian framework and employs case study research, the data from which provides suggestions to further both newer research traditions and inform policy.

\section{Summary of Research Traditions}

There is a tendency, widespread across all three research traditions, of 677 approaching studies from a mainly qualitative perspective. Quantitative approaches are often believed to overlook the 'human story' elements of the wide range of cultural and social backgrounds of migrants, especially in second-level schools. Nowlan (2008) and Fionda (2011), for example, spent time in either one or a small number of schools and used semi-structured interviews, questionnaires, and observations to build a narrative of the students' experience of school structures. This is perhaps illustrative of the motive behind studies into the context - to put the migrant students first and uncover their perspectives. Therefore even studies with a quantitative emphasis tend to illustrate findings with qualitative components. Economic and Social Research Institute $(2009,2010)$ studies are structured in such a way as to include both qualitative and quantitative elements, and Lyons and Little (2009) emphasize that 'chalk face' narratives are imperative to obtain an accurate description of haphazard educational structures. Only within the past five 
years has a more noticeable shift occurred towards more quantitative approaches in the area (see for example ESRI 2009; Mühlau et al. 2010; Parker-Jenkings and Masterson 2013; Darmody et al. 2012; Tormey and Gleeson 2012). These quantitative studies have started to map more systematically the social, cultural, political, and economic integration of various groups of immigrants in Ireland.

The research traditions all lead to the conclusion that the arrival of migrants has been useful in drawing more attention to such educational deficits, as the second research tradition (racism and discrimination at national policy level) highlights. Furthermore, studies in this area reveal a tendency to blame migration 'problems' firmly in the hands of migrants themselves. The third research tradition, which looks at education practice since the mass immigration and attempts to develop a more critical perspective, focuses on studies which observe that as society has changed the education system has struggled to keep up with it and instead maintains the cultural status quo in terms of power distribution. With Ireland's idiosyncratic context meaning there is much overlap in the traditions, in part due to the rapid pace of migration, the relative heterogeneous distribution of migrants, and then in necessary response to unstable economic conditions, the key defining features are notable. While the first research tradition, 'charting ethnic inequalities and policy issues', reviews pre-existing policy with a descriptive and analytical purpose, the second and third traditions ('racism and education' and 'developing newer and more critical research agendas') extend their methods to include qualitative analyses. The second tradition applies both quantitative and qualitative methods to describe emerging contexts, while the third tradition offers a more critical analysis in its objective of defining an ideal policy/practice paradigm.

\section{Conclusion and Discussion}

Our review of research traditions in the Irish case has indicated that there is a gap between policy documents and guidelines, and the ways in which local institutions understand and respond to diversity. Research in Ireland could therefore usefully explore how migration is managed within educational settings and what best practices have emerged including a focus on how education management understands and deals with diversity. This links to existing and new literature in the field of new managerialism in education including tracking and streaming of students (see Lynch et al. 2011). Research on differences between policy as text and policy as enacted by teachers could be 
studied more in depth and framed from appropriate theoretical angles (see Ball et al. 2012). Most recently, research conducted in the Irish primary education sector (Faas et al. forthcoming) has sought to explore the official school ethos in the 12 new community national schools in Ireland, and the extent to which there is a difference among schools in how they uphold the common guidelines underpinning ethos and identity. This includes an analysis of the extent to which the formal/lived ethos of community national schools support the promotion of diversity, tolerance and integration.

In 1999, the Primary School Curriculum in Ireland was launched and described as evolutionary rather than revolutionary because it was founded on Curaclam na Bunscoile (1971) and it was developed by the NCCA through engagement with the partners in education. The 1999 curriculum is structured in six curricular areas (e.g. religious education) with 11 subjects. Since 1999, the NCCA has produced additional guidelines to provide practical support to schools on specific aspects of curriculum and assessment such as assessment and teaching students with special educational needs. To date, the NCCA has completed two phases of review to support ongoing improvement of the curriculum in primary schools. These reviews were not a specific response to diversity or migration, but rather a general review process concerning the effectiveness of the curriculum and the extent to which it enables teachers to support children in their learning. Phase one of the review, completed in 2005, focused on English, visual arts and mathematics. Phase two, completed in 2008, focused on Irish language, science, and social, personal and health education (SPHE). There have been no changes to the SPHE curriculum as of yet following the review with the main issues highlighted being approaches to assessment and 'curriculum overload'. History and geography have yet to be reviewed. Moreover, the Irish language requirement for primary school teachers has in effect made it very difficult to recruit teachers with a migration background. In 2016, NCCA undertook a consultation process around the introduction of a common curriculum, Education about Religions and Beliefs and Ethics (ERBE) for all primary school children, but met with strong criticism from the Catholic Church. At the moment, the religion and/ or ethics programmes available in primary schools depend on the patron body, and the NCCA found big variations in content and quality.

More recently, Ireland has also become more involved in larger-scale comparative migration and education research. A European Commission report on migration and mobility (European Commission 2016) lists seven FP7 and Horizon 2020 projects, completed and ongoing, where Ireland participates as project partner. These include SOM (Support and Opposition to Migration), STYLE (Strategic Transitions for Youth Labour in Europe), YMOBILITY 
(Youth Mobility: Youth Mobility: Maximising Opportunities for Individuals, Labour Markets and Regions in the EU), WSF (Welfare State Futures), TCRAf-EU (Transnational Child Raising Arrangements between Africa and Europe), NORFACE Plus (Norface Transnational Programme on Migration in Europe), and FACSK (Family complexity and social work: A comparative study of family-based welfare work in different welfare regimes. However, very few of these studies deal explicitly with educational issues. Notable exceptions include REMC (Religious education in a multicultural society: School and home in comparative context), EMILIE (A European Approach to Multicultural Citizenship: Legal, political and educational challenges), and ACCEPT PLURALISM which investigates the meanings of tolerance in a variety of societal contexts.

There are a range of other largely unexplored migration research themes in Ireland including the interface between migration and sexuality. Research on bullying (see O'Moore 2010, 2008) could usefully focus more on homophobic bullying and link this with earlier emigration to places like the UK (see Ryan-Flood 2009) and possible return migration following the historic samesex marriage referendum in Ireland on 22 May 2015. For many young members of the lesbian, gay, bi- and transsexual community, sexual citizenship is replacing national identity as a master narrative (Valentine 2001) yet very little is known about how young people from various ethno-cultural backgrounds in Ireland negotiate their belonging and what impacts their sexuality has on mobility, migration, and general social well-being (see Röder and Lubbers 2015).

\section{Bibliography}

Ball, S. J., et al. (2012). How Schools Do Policy. Policy Enactments in Secondary Schools. London: Routledge.

Biggart, B., O'Hare, L., \& Connolly, P. (2013). A Need to Belong? The Prevalence of Experiences of Belonging and Exclusion in School Among Minority Ethnic Children Living in the 'White Hinterlands'. Irish Educational Studies, 32(2), 179-195.

Bourdieu, P. (1991). Language and Symbolic Power. Cambridge: Polity Press. Bourdieu, P. (1993). The Field of Cultural Production. Cambridge: Polity Press. Bourdieu, P., \& Passeron, J. (1977). Reproduction in Education, Society and Culture. London: Sage.

Bourdieu, P., \& Passeron, J. (1979). The Inheritors: French Students and Their Relation to Culture. Chicago: University of Chicago Press. 
Bourne, J. (2003). Vertical Discourse: The Role of the Teacher in the Transmission 806 and Acquisition of Decontextualised Language. European Educational Research 807 Journal, 2, 496-521.

Bryan, A. (2010). Corporate Multiculturalism, Diversity Management, and Positive Interculturalism in Irish Schools and Society. Irish Educational Studies, 29(3), 253-269.

Byrne, D., McGinnity, F., Smyth, E., \& Darmody, M. (2010). Immigration and School Composition in Ireland. Irish Educational Studies, 29(3), 271-288.

Central Statistics Office (CSO). (2012). Population and Migration Estimates: April 2012. Dublin: CSO.

Central Statistics Office. (2016). Population and Migration Estimates: April 2016. Dublin: CSO.

Central Statistics Office (CSO). (2017). Census 2016 Summary Results - Part 1. Dublin: CSO.

Crozier, G., Bhopal, K., \& Devine, D. (2010). Editorial. Irish Educational Studies, 29(3), 207-212.

Cummins, J. (2000). Language, Power and Pedagogy - Bilingual Children in the Crossfire. Clevedon: Multilingual Matters.

Darmody, M., Smyth, E., Byrne, D., \& McGinnity, F. (2012). New School, New System: The Experiences of Immigrant Students in Irish Schools. International Handbook of Migration, Minorities and Education 2012, 2, 283-229.

Darmody, M., Byrne, D., \& McGinnity, F. (2014). Cumulative Disadvantage? Educational Careers of Migrant Students in Irish Secondary Schools. Race Ethnicity and Education, 17(1), 129-151.

Department of Education and Science. (1998). The Education Act. Dublin: DES. http://www.irishstatutebook.ie/1998/en/act/pub/0051/print.html

Department of Education and Skills. (2003). Summary of All Initiatives Funded by the Department to Help Alleviate Educational Disadvantage. Dublin: DES.

Department of Education and Skills. (2004). A Brief Description of the Irish Education System. Dublin: DES.

Department of Education and Skills. (2007). Circular 0053/2007-Meeting the Needs of Pupils for Whom English Is a Second Language. Dublin: DES.

Department of Education and Skills. (2009). Circular 0015/2009-Meeting the Needs of Pupils Learning English as an Additional Language (EAL). Dublin: DES.

Department of Education and Skills. (2011). Language Support for Migrants: A Value for Money Review of Expenditure on the Education of Migrant Students at Primary and Post-Primary Level Who Do Not Speak English (or Irish) as a First Language. Dublin: DES.

Department of Education and Skills. (2012). Circular 0009/2012 - Staffing Arrangements in Post-primary Schools for the 2012/13 School Year. Dublin: DES. Analysis. Irish Educational Studies, 18, 14-28.

Devine, D. (2005). Welcome to the Celtic Tiger? Teacher Responses to Immigration and Increasing Ethnic Diversity in Irish Schools. International Studies in Sociology of Education, 15, 49-70. 
Devine, D. (2011a). Immigration and Schooling in Ireland - Making a Difference? Manchester: Manchester University Press. In Darmody, M., Tyrrell, N., and Song, S. (Eds.), The Changing Face of Ireland. Rotterdam: Sense Publishers.

Devine, D. (2011b). Securing Migrant Children's Educational Well-Being: Perspectives on Policy and Practice in Irish Schools. In Ethnic Minority Children and Youth in Ireland. Amsterdam: Springer.

Economic and Social Research Institute. (2009). Adapting to Diversity: Irish Schools and Newcomer Students, Research Series. Dublin: ESRI.

Economic and Social Research Institute. (2010). Religious Education in a Multicultural Society: School and Home in Comparative Context. https://www.esri.ie/pubs/ BKMNEXT214.pdf.

European Commission. (2016). Research and Innovation Projects in Support to European Policy: Migration and Mobility. Luxembourg: Publications Office of the European Union.

Eurydice. (2009). Organisation of the Education System in Ireland. http://eacea.ec. europa.eu/education/eurydice/documents/eurybase/eurybase_full_reports/ IE_EN.pdf

Faas, D. (2010). Negotiating Political Identities: Multiethnic Schools and Youth in Europe. Farnham: Ashgate.

Faas, D., \& Ross, W. (2012). Identity, Diversity and Citizenship: A Critical Analysis of Textbooks and Curricula in Irish Schools. International Sociology, 27(4), 574-591.

Faas, D., Sokolowska, B., \& Darmody, M. (2015). Everybody Is Available to Them': Support Measures for Migrant Students in Irish Secondary Schools. British Journal of Educational Studies, 63(4), 447-466.

Faas, D., Darmody, M., \& Sokolowska, B. (2016). Religious Diversity in Primary Schools: Reflections from the Republic of Ireland. British Journal of Religious Education, 38(1), 83-98.

Faas, D., Smith, A., \& Darmody, M. (forthcoming). Between Ethos and Practice: Are Ireland's New Multi-denominational Primary Schools Equal and Inclusive? School Leadership and Management.

Ferguson, G. (2006). Language Planning and Education. Edinburgh: Edinburgh University Press.

Fionda, R. (2011). Education Is a Fundamental Right: Do Immigrant Students Have Equal Access to Second Level Education in Ireland? Translocations 7.1. http:// www.translocations.ie/docs/v07i01/Vol\%207\%20Issue\%201\%20-\%20Peer\%20 Review\%20-\%20Education\%20\&\%20Immigrants,\%20Fionda.pdf

Fionda, R. (2013). Teaching English to Immigrant Students in Irish Post-primary Schools. In D. Little, C. Leung, \& P. Van Avarmaet (Eds.), Managing Diversity in Education. Clevedon: Multilingual Matters.

Fischman, G., \& Mclaren, P. (2005). Rethinking Critical Pedagogy and the Gramscian and Freirean Legacies: From Organic to Committed Intellectuals or Critical Pedagogy, Commitment, and Praxis. Cultural Studies $\leftrightarrow$ Critical Methodologies, 5, 425-446. 
Gramsci, A. (1971). Selections from the Prison Notebooks. London: Lawrence and Wishart.

Gray, B. (2006). Migrant Integration Policy: A Nationalist Fantasy of Management and Control. Translocations, 1(1), 121-141.

Guerin, P. (2002). Racism and the Media in Ireland: Setting the Anti-Immigrant Agenda. In R. Lentin \& R. McVeigh (Eds.), Racism and Anti-Racism in Ireland. Belfast: Beyond the Pale.

Hannan, D. F., Raffe, D., \& Smyth, E. (1996). Cross-National Research on School to Work Transitions: An Analytical Framework. Paris: OECD.

Hyland, A. (1999). Inclusiveness in Education. In N. Ward \& T. Dooney (Eds.), Irish Education for the 21st Century. Dublin: Oak Tree Press.

Integrate Ireland Language and Training. (2007). A Resource Book for Language Support in Post-Primary Schools. Dublin: IILT.

Irish National Teacher Organisation. (2005). Intercultural Education in the Primary School. http://www.into.ie/ROI/Publications/InterculturalEd.pdf.

Keogh, A., \& Whyte, J. (2003). Getting on: The Experiences of Immigrant Students in Second Level Schools Linked to the Trinity Access Programmes. Dublin: Children's Research Centre, Trinity College Dublin.

Kitching, K. (2010). An Excavation of the Racialised Politics of Viability Underpinning Education Policy in Ireland. Irish Educational Studies, 29(3), 213-229.

Kitching, K. (2013). Governing 'Authentic' Religiosity? The Responsibilisation of Parents Beyond Religion and State in Matters of School Ethos in Ireland. Irish Journal of Sociology, 21(1), 17-34.

Kuhling, C., \& Keohane, K. (2007). Cosmopolitan Ireland. London: Pluto Press. 917

Lentin, R. (2002). Anti-racist Responses to the Racialisation of Irishness: Disavowed Multiculturalism and Its Discontents. In R. Lentin \& R. McVeigh (Eds.), Racism and Anti-racism in Ireland. Belfast: Beyond the Pale.

Lentin, R., \& McVeigh, R. (2006). After Optimism: Ireland, Racism and Globalisation. Dublin: Metro Éireann Publications.

Little, D. (2008). Language Learner Autonomy and the European Language Portfolio: Two English Examples. Language Teaching, 42, 222-233.

Little, D., \& Lazenby-Simpson, B. (2004). Using the CEF to Develop an ESL Curriculum for Newcomer Pupils in Irish Primary Schools. In K. Morrow (Ed.), Insights from the Common European Framework. Oxford: OUP.

Lynch, K., Devine, D., \& Grummell, B. (2011). New Managerialism and the Care Ceiling in Education. London: Palgrave Macmillan. 
McGarry, P. (2017, July 21). Archbishop Proved Right About School Patronage. The Irish Times. http://www.apastyle.org/learn/faqs/cite-newspaper.aspx. Retrieved.

McGinnity, F., Quinn, E., O'Connell, P., \& Donnelly, N. (2011). Immigration Monitor Ireland 2010. Dublin: ESRI.

McGinnity, F., Quinn, E., Kingston, G., \& O’Connell, P. (2012). Immigration Monitor Ireland 2011. Dublin: ESRI.

McGinnity, F., Quinn, E., Kingston, G., \& O’Connell, P. (2013). Immigration Monitor Ireland 2012. Dublin: ESRI.

McGinnity, F., Quinn, E., Kingston, G., \& O’Connell, P. (2014). Immigration Monitor Ireland 2013. Dublin: ESRI.

McVeigh, R. (2002). Is There an Irish Anti-racism? Building an Anti-Racist Ireland. In R. Lentin \& R. McVeigh (Eds.), Racism and Anti-racism in Ireland. Belfast: Beyond the Pale.

Mills, C., \& Gale, T. (2007). Researching Social Inequalities in Education: Towards a Bourdieuian Methodology. International Journal of Qualitative Studies in Education, 20(4), 433-447.

Mühlau, P., Kaliszewska, M., \& Röder, A. (2010). Polonia in Dublin: Preliminary Report of Survey Findings (Report No. 1, Demographic Overview). Dublin: Trinity Immigration Initiative Trinity College Dublin.

National Council for Curriculum and Assessment. (2006). Intercultural Education in the Post-primary School. Dublin: DES.

Nowlan, E. (2008). Underneath the Band-Aid: Supporting Bilingual Students in Irish schools. Irish Educational Studies, 27, 253-266.

Ó Riagáin, P. (2013). The Linguistic Challenge of Multi-cultural Ireland: Managing Language Diversity in Irish Schools. In J. Ulin, H. Edwards, \& S. O'Brien (Eds.), Race and Immigration in the New Ireland (pp. 107-129). South Bend: University of Notre Dame Press.

O'Connor, L., \& Faas, D. (2012). The Impact of Migration on National Identity in a Globalized Word: A Comparison of Civic Education Curricula in England, France and Ireland. Irish Educational Studies, 31(1), 51-66.

O’Moore. (2008). Preventing School Bullying: The Irish Experience. In D. Pepler \& W. Craig (Eds.), Understanding and Addressing Bullying. Bloomington: Authorhouse.

O'Moore, M. (2010). Understanding School Bullying: A Guide for Parents and Teachers. Dublin: Veritas.

Organization for Economic Cooperation and Development. (2009). Reviews of Migrant Education: Ireland. Paris: OECD.

Organization for Economic Cooperation and Development. (2010). PISA 2009 Results Learning Trends: Changes in Student Performance Since 2000. Paris: OECD.

Parker-Jenkins, M., \& Masterson, M. (2013). No Longer 'Catholic, White and Gaelic': Schools in Ireland Coming to Terms with Cultural Diversity. Irish Educational Studies, 32(4), 477-492.

Reay, D., Crozier, G., \& James, D. (2011). White Middle Class Identities and Urban Schooling. Basingstoke: Palgrave Macmillan. 
Röder, A., \& Lubbers, M. (2015). Attitudes Towards Homosexuality Amongst Recent Polish Migrants in Western Europe: Migrant Selectivity and Attitude Change. Journal of Ethnic and Migration Studies, 41(11), 1858-1884.

Ruhs, M. (2005). Managing the Immigration and Employment of Non-EU Nationals in Ireland. Dublin: The Policy Institute, Trinity College Dublin.

Ruhs, M. (2009) Ireland: From Rapid Immigration to Recession. Migration Policy Institute. http://www.migrationinformation.org/Feature/display.cfm?ID=740

Ryan-Flood, R. (2009). Lesbian Motherhood: Gender, Families and Sexual Citizenship. Basingstoke: Palgrave Macmillan.

Smyth, E. (1999). Do School Differ? Academic and Personal Development among Pupils in the Second-Level Sector. Dublin: Oak Tree Press.

Smyth, E., McCoy, S., Darmody, M., \& Dunne, A. (2007). Changing Times, Changing Schools? Quality of Life for Students. In T. Fahey, H. Russell, \& C. Whelan (Eds.), Best of Times? The Social Impact of the Celtic Tiger. Dublin: Institute of Public Administration.

Stevens, P. (2007). Researching Race/Ethnicity and Educational Inequality in English 996 Secondary Schools: A Critical Review of the Research Literature between 1980 and 2005. Review of Educational Research, 77(2), 147-185.

Stevens, P., Clycq, N., Timmerman, C., \& Van Houtte, M. (2011). Researching Race/Ethnicity and Educational Inequality in the Netherlands: A Critical Review of the Research Literature between 1980 and 2008. British Educational Research Journal, 37(1), 5-43.

Tannam, M., Smith, S., \& Flood, S. (1998). Anti-racism: An Irish Perspective. Dublin: Harmony.

Teaching Council. (2013). Programmes of Initial Teacher Education. Retrieved from: 1005 http://www.teachingcouncil.ie/en/Publications/Teacher-Education/ Documents/2013-10-31-Programmes-of-Initial-Teacher-Education.pdf

Turner, T. (2010). Why are Irish Attitudes to Immigrants Among the Most Liberal in Europe? European Societies, 12(1), 25-44.

Ward, T. (2006). Education and Language Needs of Separated Children. http://www. 